\title{
Mercury and soil carbon dioxide analysis to determine geothermal potential in Mt. Telomoyo, Central Java. Indonesia
}

\author{
Rifqi Alfadhillah Sentosa ${ }^{1}$, Hasbi Fikru Syabi ${ }^{1}$, Agil Gemilang Ramadhan ${ }^{1}$, Boy \\ ${\text { Yoseph } \operatorname{CSSSA}^{1} \text {, Soetoyo }}^{2 *}$ \\ ${ }^{I}$ Department of Geological Engineering, Padjadjaran University \\ ${ }^{2}$ Geological Agency of Indonesia \\ Jl. Raya Bandung Sumedang Km. 21, Sumedang 45363 - Indonesia.
}

\begin{abstract}
Mercury and soil carbon dioxide are two of many elements that can be used to determine geothermal source potential. The simple concept is that these elements are commonly present in geothermal fluids and usually reside on rocks or soil along its migration path while going onto the surface through porosities. The research is located at Mt.Telomoyo, Central Java Province, located approximately 400 kilometres east-southeast of Jakarta. Around the mountain, four hot springs and four cold springs were found, as well as 144 soil samples. This study aims to determine the geothermal source by using soil geochemical analysis which uses mercury and carbon dioxide as analysed elements. Methods of mercury and carbon dioxide analysis were also aided by Fault-and-Fracture analysis in the study area. The anomaly map of both elements and the fracture density shows anomalies in the same location thas is at the north side of Mt. Telomoyo. This anomaly zone is indicated as a geothermal potential area in the study area.
\end{abstract}

Keywords: Mercury Analysis, Soil Carbon Dioxide, Soil Geochemistry, FFD, Mt. Telomoyo

\section{Introduction}

Mount Telomoyo is a volcano located at administrative border of Magelang and Semarang Regency. This mountain has a height of 1,894 meters above sea level, is no longer active since quarter period, and has a strato-shaped but also has never recorded erupted. This mountain is flanked by Mount Merbabu, Mount Andong, Mount Sumbing, and Mount Ungaran. Mount Telomoyo appears to the south of this depression as high as $600 \mathrm{~m}$ from the base of the basin. In this area, there are other volcanoes older than it namely Kendapi Volcano and Gilipetung Volcano [1].

People live in vicinity usually hike Mount Telomoyo out of fun, as the summit presents amazing view since one can see a lined up tall mountains of Mount Lawu, Mount Sumbing, Mount Sindoro, and Mount Prau. People also usually come to witness a vast lake of Rawa Pening from above. This mountain is quite popular in Central Java, though not as popular as Mount Merbabu for its hiking experience and views, but Mount Telomoyo has an easy access to its top as there is vehicle road, whick makes many local and even also international tourist chooose this mountain as their travel destination.

Previous research conducted by Pertamina from 1988-1993 in the form of geological, geochemical, geophysical data collection and gradient thermal temperature data. In 2010, Geological Agency of Indonesia has conducted an integrated survey of geology and geochemistry as well as magneto telluric survey in this area. The results of previous research shows that this geothermal area Telomoyo has

\footnotetext{
* Manuscript received August 7, 2018; revised March 9, 2019.

Corresponding author. E-mail address: rifqi14008@mail.unpad.ac.id

doi: 10.12720/sgce.8.3.313-319
} 
excellent geothermal potential to be developed. As for the purpose of this research is to determine potential areas of Telomoyo geothermal mainly using mercury and carbon dioxide analysis in study area soil samples.

Chemical data of this study came from Geological Agency of Indonesia in 2010, which deployed a survey team to do geology and geochemistry exploration of Candi Umbul-Telomoyo. There are 144 soil samples in the study area, with mercury concentrations from $20 \mathrm{ppb}$ to $930 \mathrm{ppb}$ and $\mathrm{CO}^{2}$ concentrations from $0.14 \%$ to $9.78 \%$ [2]. The purpose of this research is to know the anomaly of mercury and carbon dioxide in soil and Fault-and-Fracture Density analysis in the study area, and to know correlation of those anomalies with geothermal potential existense in study area.

Candi Umbul-Telomoyo geothermal area located in the eastern side (Figure 1). In this zone is formed a complex which extends NW-SE, i.e. Mount Telomoyo-Mount Merbabu-Mount Merapi volcano which is located in the volcanic geology of Quaternary [3]. The products of volcanoes are pyroclastic and lava rocks with compositions-basaltic.

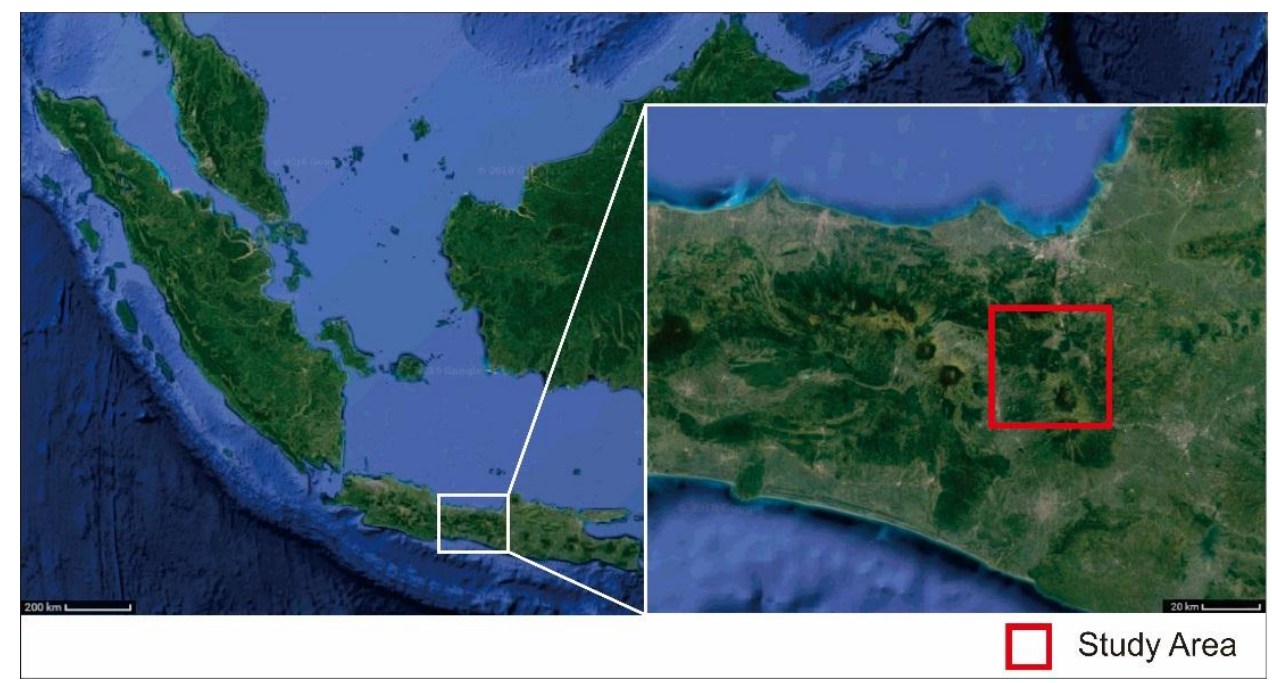

Fig. 1. Mt. Telomoyo and its surrounding. The mountain itself marked with red marker, approx. 400 kilometers from Jakarta, capital city of Indonesia.

\section{Geological Setting}

\subsection{Tectonic and geological structures}

Tectonic activity in this study area begin at Early Tertiary, proved by basaltic and andesitic intrusion, then followed by upliftting and erosion. This erosion formed turbidites of the Kerek formation in neritic environment which is subsequently followed by the Kalibeng formation in a bathyal environment and basin filling of the Damar Formation in a transitional to terrestrial environment [4]. The geologic structures in this study area forming dominantly E-W asymetrical folds, followed by E-W thrust, NE-SW and NW-SE strike slip faults also normal fault. The occuring fractures forms a weak zone for the rise of young quartenary volcanic rocks [4].

\subsection{Stratigraphy}

The stratigraphy of the study area (Fig. 2) is composed of rocks from the youngest to the oldest formations, as follows:

- Alluvium: pebble, cobble, sand and silt range in thickness about 1-3 m. Blocks found are composed of andesite, limestone, and sandstone. 
- Deposits of cinder cone consist of deeply weathered fine grained tuff, breccia, and porphyritic andesite.

- Basalt.

- Mt. Sumbing Lava, consist of lava flows and dome.

- Merbabu Volcanics, consisting of basalt and andesite.

- Telomoyo Volcanics, consist of lava andesitic.

- Andong and Kendil Volcanics, consist of andesite breccia.

- Gilipetung Volcanics, consisting of fine-grained vesicular lava flows.

- Blalak Volcanics, consist of andesite porphyritic.

- Kaligetas Formation, consist of volcanics breccia, lava flows, tuff, tuffaceous sandstone and claystone.

- Payung Formation, consist of lahar, claystone, breccia, and tuff.

- Penyatan Formation, consist of sandstone, breccia, tuff, claystone and lava flows.

- Kerek Formation, consist of claystone, marl, tuffaceous, sandstone, conglomerate, volcanic, breccia and limestone.

- Andesite as intrusive rocks.

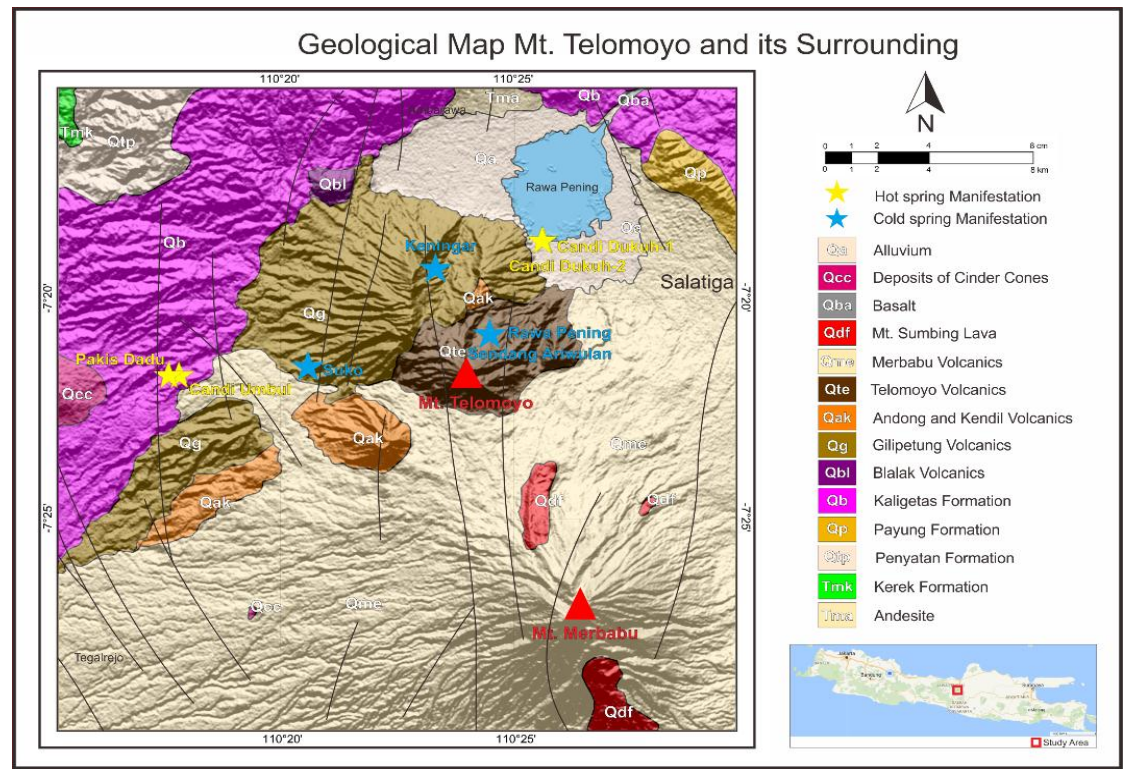

Fig. 2. Geological Map of Study Area

\subsection{Surface manifestation}

In the study area, there are four surface manifestations, namely Candi Dukuh-1, Candi Dukuh-2, Candi Umbul, Pakis Dadu and four cold water springs i.e. Rawa Pening, Suko, Sendang Ariwulan, Keningar.

\section{Method}

\subsection{Fault-and-fracture density}

Fault-and-Fracture Density Method is done delineating lineaments on SRTM 1 Arc-Second Map with $30 \mathrm{~m}$ resolution (Figure 3). Shaded relief is used to set angles of pseudo sun as the source of the light ray, so the lineaments on study area can be shown maximally. In this study, four azimuths of light direction used to show the lineaments, i.e. $0^{\circ}, 45^{\circ}, 90^{\circ}$, and $315^{\circ}$. Altitude of the light is set by $45^{\circ}$. Such methods are available in GIS software, such as Global Mapper, ArcGIS, and MapInfo.

Delineated lineaments are grouped into $5 \mathrm{~km}$ x $5 \mathrm{~km}$ grid and measured by the lengths. Total length values of each grid then plotted at the center of its grid and represent as lineament density. This step is to 
create lineament density map, that is a contour map based on the value of lineament density in each grid. Lineament density map is later interpreted and correlated to every surface manifestations found in the study area and also to their thermal fluid features [5].

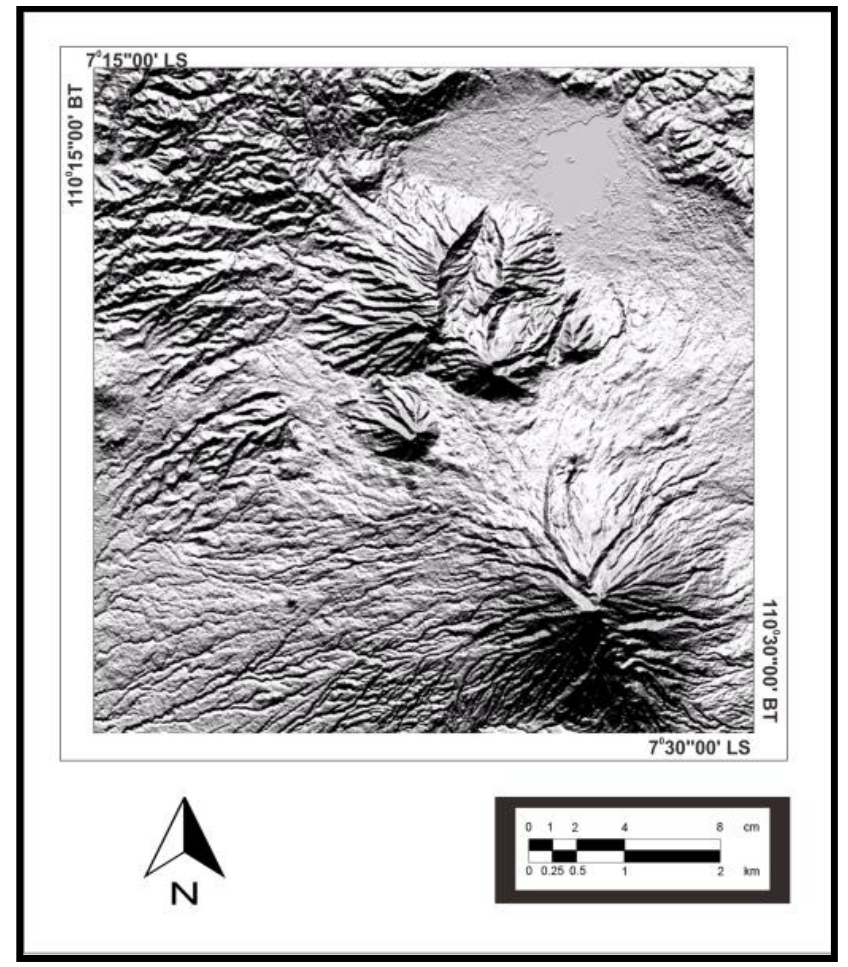

Fig. 3. Digital Elevation Model of Study area.

\subsection{Mercury analysis}

The concentration of mercury on soil is influenced by several factors, such as the formation of chelates absorption on clay, or ion exchange. Under certain conditions the geothermal activity affects the concentration of mercury on the soil, which will make the mercury concentration very high. Anomalous concentration of mercury on soil can be used to determine the existence of geothermal activity of an area at exploration stage in green area.

In this study made map of mercury distribution based on mercury concentration (ppb) in soil at 144 point in research area using Kriging method. Then mercury anomaly area which shows high concentration of mercury in research area are determined.

\subsection{Carbon dioxide analysis}

Carbon dioxide in the is caused by the trapping of the gas in the soil at the time of release of the gas from below the surface. In areas affected by geothermal activity, the concentration of carbon dioxide is high percentage compared to other regions. Map of soil $\mathrm{CO}^{2}$ distribution is created based on soil $\mathrm{CO}^{2}$ concentration in 144 point of research area using Kriging method. After that, the anomaly area is determined. 


\section{Result}

Every methods used in this research resulted in respective maps as you can see each details below.

\subsection{Fault-and-fracture density map}

Four azimuths of illumination used to extract all of lineaments in study area i.e. $0^{\circ}, 45^{\circ}, 90^{\circ}$, and $315^{\circ}$. All of lineaments compiled into one map and the study area converted into grids. The lineaments converted into a map based on the length of lineaments in each grid. The most suitable grid area in the alignment density analysis of a geothermal field is $1 \mathrm{~km}$ with the unit obtained being $\mathrm{km} / \mathrm{km}^{2}$ [6].

The resulted map shows even distribution of lineament density in the study area. Based on the result, FFD value in study area ranged from $13-4400$ metres (Figure 4). As for the highest density of lineament are located around Mt. Telomoyo itself, at the northern side of the mount for the exact. High density of lineament showed with orange to red zones.

\subsection{Mercury anomaly map}

The mercury anomaly distribution map is used to determine the geothermal potential area. Mercury concentration in soil is influenced by atmospheric parameter. Most soils retain mercury by formation of chelates, by absorption on clays, or by ion exchange. Soil characteristics like $\mathrm{pH}$, clay content and organic content influence the mercury distribution in soils, but geothermal activity introduces mercury in sufficient amounts to overwhelm local background variations [7].

The distribution map of mercury anomaly is made from plotting mercury content value of soil samples. Based on the mercury anomaly distribution map (Figure 5) it was found that mercury anomaly was at the northern side of Mt. Telomoyo showed as yellow to red color.

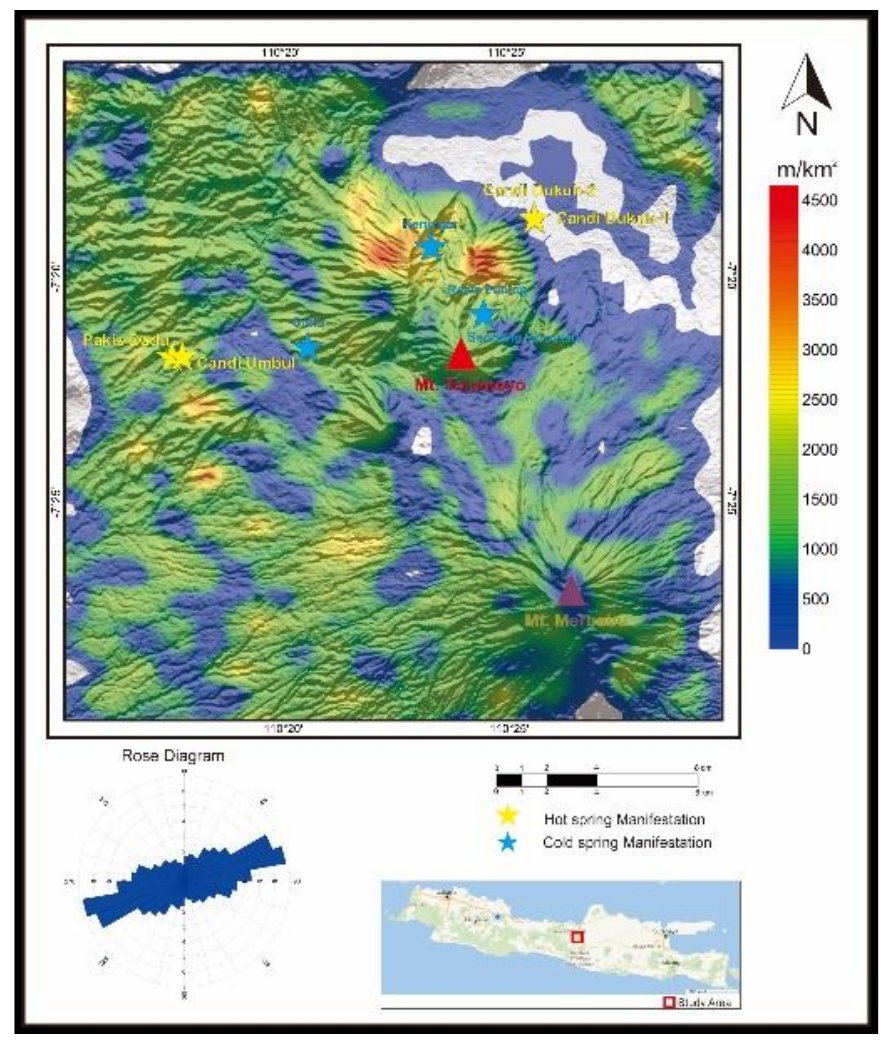

Fig. 4. Fault and Fracture Density Map as The Result of Fault and Fracture Density Analysis. 


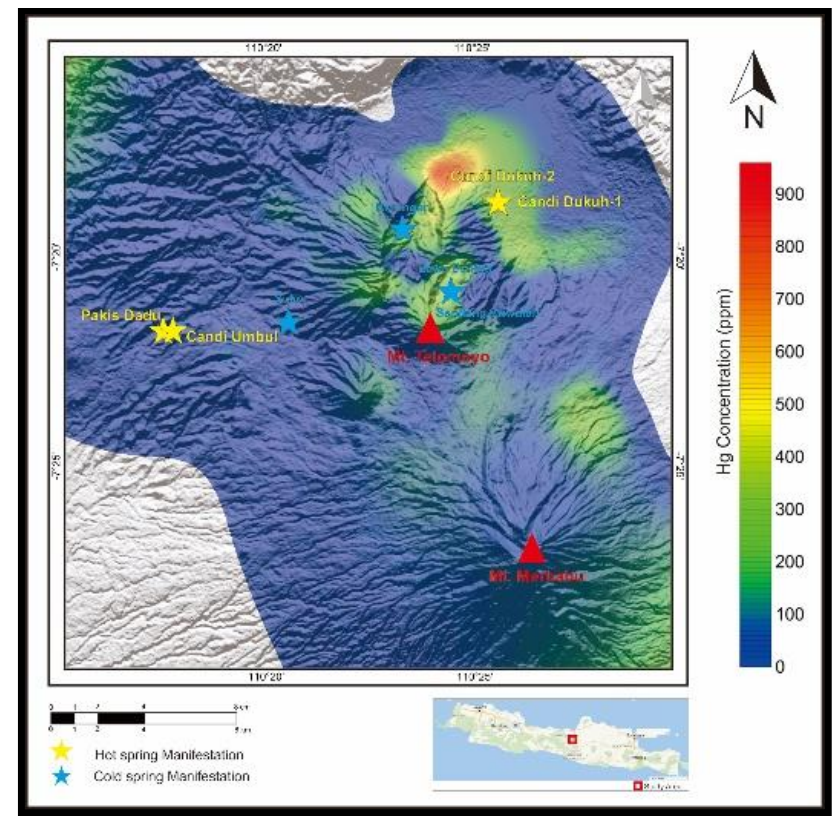

Fig. 5. Mercury Distribution Map on Study area.

\section{3. $\mathrm{CO}^{2}$ anomaly map}

The carbon dioxide anomaly distribution map is also used to determine the geothermal potential area. Volcanoes release gases also on their flanks by diffuse degassing of gaseous species such as carbon dioxide $\left(\mathrm{CO}^{2}\right)$. Whereas the high-temperature gases in craters tend to be reactive, $\mathrm{CO}^{2}$ does not react with country rocks. The distributions and quantities of the gases provides information on the overall permeability of a volcanic edifice, the potential for lateral degassing from areas other than the active crater and the ability of a volcano to diffusely release large quantities of $\mathrm{CO}^{2}$ and the other gases (Malimo, 2012) [8].

The resulted map of $\mathrm{CO}^{2}$ distribution (Figure 6) shows an evenly distributed $\mathrm{CO}^{2}$ gas in study area based on the soil samples. The $\mathrm{CO}^{2}$ anomalies were found near Candi Dukuh hot spring at the northern side of Mt. Telomoyo, and Candi Umbul hot spring which located at western side of the mount.

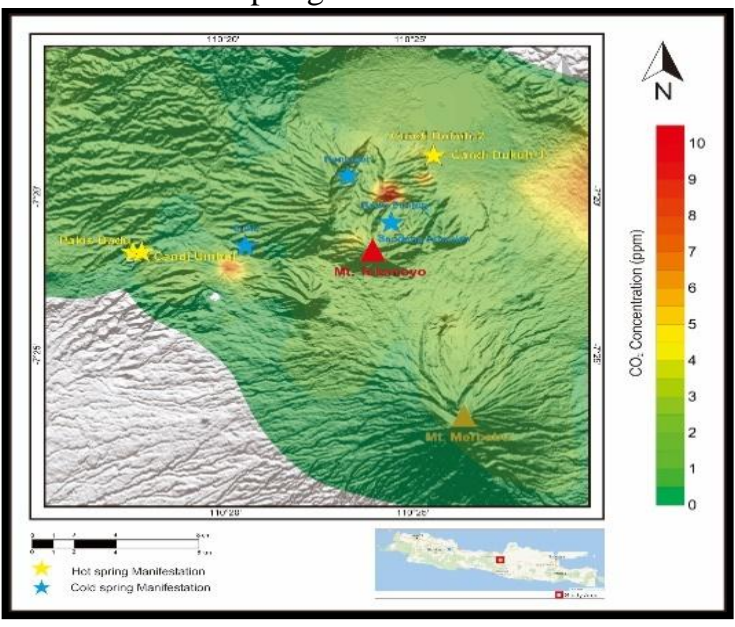

Fig. 6. $\mathrm{CO}^{2}$ Distribution Map on Study area. 


\section{Conclusion}

Based on FFD calculation in study area, the values ranged about $13-4400$ metres distributed on Mount Telomoyo geothermal area. Up to $930 \mathrm{ppb}$ of mercury concentration and also up to $9.78 \%$ of $\mathrm{CO}^{2}$ concentration found in 144 soil samples in study area [2]. The result of this study shows that the geothermal potential zone in the region is located at the northern side of Mt. Telomoyo. This conclusion resulted from compiling each resulted maps above and interpret the zone that shows positive geothermal occurrences of each maps i.e. Fault and Fracture Density, mercury anomaly, and CO2 anomaly

It shows on all the same result of used methods which can be concluded that there is a correlation between mercury analysis, $\mathrm{CO}^{2}$ analysis, and also FFD methods in determining geothermal potential area.

\section{References}

[1] Ramadhan N, Prameswari M, Harijoko A. Evaluasi Kondisi Geologi dan Geokimia Potensi Panasbumi Gunungapi Telomoyo, PROSIDING SEMINAR NASIONAL KEBUMIAN KE-7,

[2] Geological Resource Center Survey Team, 2010, Laporan Survei Terpadu Geologi dan Geokimia Daerah Panas Bumi Candi Umbul-Telomoyo, Provinsi Jawa Tengah, Bandung : Pusat Sumber Daya Geologi.

[3] Hermawan, Dudi. Rezky, Yuanno. (2011). Delineasi Daerah Prospek Panas Bumi Berdasarkan Analisis Kelurusan Citra Landsat di Candi Umbul - Telomoyo, Provinsi Jawa Tengah,” Buletin Sumber Daya Geologi Volume 6 Nomor 1- 2011.

[4] Thanden RE, et al. (1996), "Peta Geologi Lembar Magelang dan Semarang, Jawa skala 1 : 100.000," Bandung : Pusat Penelitian dan Pengembangan Geologi.

[5] Sentosa, Rifqi A. Syabi, Hasbi F. Haryanto, Iyan., 2017, Structural Geology Analysis Using Remote Sensing Method and Its Correlation to Geothermal Occurence at Lebak Regency, Banten, Jakarta : Proceedings The 5th Indonesia International Geothermal Convention \& Exhibition (IIGCE) 2017.

[6] Soengkono S, Te Kopia Geothermal System (New Zealand) - the relationship between its structure and extent, Geothermics, 28 (1999a): 767-784.

[7] Varekamp JC, Buseck PR. 1983, mercury Anomalies in Soils: A Geochemical Exploration Method for Geothermal Areas, Geothermics.

[8] Malimo, Sylvia J, 2012, Use of Radon and Carbon Dioxide in Geochemical Exploration of Menengai and Silali Geothermal Prospects, Kenya, Nairobi, Proceedings of the 4th African Rift Geothermal Conference 2012. 